\title{
STAATKUNDIGE STROMINGE IN TRANSVAAL IN DIE JARE 1836-1857.
}

\section{VAN DERDEPOORT NA SANDRIVIER.}

Die eenheid wat in Derdepoort deur die afwesigheid van Bührmann bereik was, sou egter van korte duur wees. Die volksraad van die verenigde groepe het op 19 September 1849 vir die eerste keer saamgekom. Bührmann was weer gesond en het genoeg tyd gehad om voor die vergadering te organiseer en die sake deurmekaar te maak. Hy was op die vergadering onder die publiek aanwesig en sy invloed het baie versteurend gewerk.

Die Raad het nie op Ohrigstad saamgekom nie. Die koorssiekte sowel as die politieke onenigheid het gemaak dat baie mense daar weggetrek het en die plek byna verlate was, en die plan was dan ook om n nuwe dorp aan te lê, en op hierdie sitting sou oor die plek en die naam besluit word.

Die Raad het op Krugerspost saamgekom, omtrent 30 myl ten suide van Ohrigstad. Dit was egter glad nie 'n weerspieëling van die eenheid wat op Derdepoort bereik was nie. Met die opening was daar sestien lede aanwesig waarvan minstens nege tot die ou Ohrigstadse minderheidsparty behoort nie. Potgieter was nie daar nie, want hy wou hom nie langer aan die beledigings van Bührmann blootstel nie. Pretorius kon nie sitting neem nie, want hy moes hom deur 'n hofsaak teen W. H. Jacobsz verdedig. Bührmann het onder die publiek hard gewerk om stemming teen Pretorius te wek. Jacob de Clercq, die ou vriend van die gestorwe J. J. Burger, is tot voorsitter gekies. Die aanwesige publiek het toe nog vier lede bygekies, waarvan drie van dié Ohrigstadse party was. Hierdie party het dan ook oorheers, en die Raad het skaars begin toe die voorsitter die notule voorgelê het van 'n byeenkomste wat op 3 April op Ohrigstad gehou is, ${ }^{1}$ ) dus sewe weke voor die vergadering op Derdepoort, en waar besluit is om te verenig op voorwaarde dat twee van die drie sittings van die Raad wat elke jaar gehou sou word, op Ohrigstad moes plaas vind, en dat die helfte van die Volksraadslede -12 van die 24 - van die distrik Ohrigstad moes wees. Hierdie besluite was nooit op die Raadsvergadering op Derdepoort ter tafel nie, en nou hier op Krugerspost het die Raad dit, nadat die vereniging reeds beklonke was, agteraf goedgekeur, en daaraan toegevoeg dat Ohrigstad, of die nuwe plek wat in die plek daarvan sou kom, die hoofstad van die land sou wees. $\left.{ }^{3}\right)$

Hierdie besluit was die toppunt van eienaardigheid, nie alleen deur die wyse waarop dit geneem is nie, maar veral omdat dit aan die

1) Soutter Kolleksie 1. No. 10.

2) Volksraadsnotule 19 Sept. 1849, Art. 2. 
inwoners van Ohrigstad wat ver in die minderheid was, die reg gegee het op die helfte van die volksraadslede, en om twee van die drie Raadsittings daar te hê. Dit was niks anders nie dan 'n slinkse manier van die Ohrigstadters om die aanhangers van Potgieter en Pretorius onder hulle uit te forseer. Dit was 'n weerspieëling van die gees van Bührmann wat Potgieter en Pretorius wou klein kry. Hy het op die Ohrigstadse vergadering van 3 April waar hierdie besluite geneem is, dan ook reeds verklaar "dat de macht en invloed van den Heeren A. H. Potgieter en A. W. J. Pretorius nu vernietigd was". Daar was dus nie 'n eerlike vereniging nie, maar 'n vernietiging van Potgieter en Pretorius.

Hierdie besluit het gemaak dat die Volskraad in westelike Transvaal vrywel geen gesag gehad het nie, net so $\mathrm{min}$ as in die noorde, en in die eersvolgende jare sou die Lydenburgers met Bührmann die res van die Republiek oorheers ${ }^{3}$ ), wat baie twis en verdeeldheid sou veroorsaak en wat op die afskeiding van Lydenburg sou uitloop.

Pretorius kon nie sitting neem nie. Daar was 'n hofsaak tussen hom en W. H. Jacobsz. Laasgenoemde het hom beskuldig le dat hy sy invloed gebruik het om die mense in 1842 in Natal onder Britse gesag te bring, $2 \mathrm{e}$ dat hy in 1847 as gesant na Sir Henry Pottinger sy plig nie gedoen het nie, $3 e$ dat hy na die slag van Boomplaas witvoetjie by Sir Harry Smith gesoek het. Die hof het egter uitgespreek dat voor hierdie drie punte bewys kon word daar geen vonnis gevel kon word nie. Pretorius het dus gewen. ${ }^{*}$ ) $\mathrm{Na}$ afloop van hierdie hofsaak kon Pretorius en Jacobsz eers as raadslede insweer. ${ }^{6}$ ) Hierna het die Raad besluit om 'n nuwe dorp te stig met die naam van Lydenburg.") Teenoor Potgieter het die Raad die mees onverdraagsame houding ingeneem. Hy is met nog ses ander van sy mense gedagvaar om hom voor ' $n$ hof te kom verantwoord waarom hy by Olifantsrivier uit die vergadering weggestap het, en dit is besluit om desnoods in gewapende mag teen hom te gebruik, en Zoutpansberg in in staat

3) Vier jaar later, 7 Desember 1843 het DS. D. VAN DER HoFf aan Prof. Lauts geskryf: ..Nu heeft Lijdenburg dat het kleinste is. het meeste aantal leden in de raad en Mooirivier. dat het grootste is, het minste. Het is dus meer dan billijk om die onenigheid weg te nemen, doch dit ontmoet van de Lijdenburgsche leden een sterke tekenwerking. Thans wilde men dit hier reeds tot stand brengen. doch is niet doorgegaan. Nu, weet ik, zal men een anderen weg inslaan. Men zal de weg van wettige petitionering inslaan en zulk eene petitie inleveren bij de eerstvolgende zitting van de raad, die plaats hebben zal in Junij 1854 te Rustenburg. Als de raad zich dan nog blijft versetten, vrees ik het ergste". Sien S. P. ENGELBRECHT: Gesch. Ned. Herv. Kerk (eerste druk 1920) deel I. bylae bls. CIII.

4) R. 190/50; R. 189a 49, Voortr. Arg. stukke bls. 403-416. Dit is onbegryplik hoe DR. PReller in sy lewe van Andries Pretorius, bls 372 kan beweer dat Pretorius nul op die rekes gekry het!

5) Volksraadsnotule Art. 20.

6) Volkstaadsnotule Art. 22 en $22 \mathrm{a}$. 
van blokkade te plaas.') Hulle wou eers in kommando na Zoutpansberg stuur om hom te gaan vang, en mens kry die indruk dat dit Pretorius was wat voorkom het dat hulle so'n besluit geneem het. ${ }^{8}$ ) Net as of so n optrede iets sou bydra tot versoening!

Potgieter en Pretorius moes opsy gesit word. en daarom besluit die Raad verder dat van heden af voortaan geen hoofcommandant of generaal zal bestaan". $\left.{ }^{2}\right)$ Ohrigstad het dus heeltemaal geseëvier, en nie alleen Pretorius maar ook Potgieter is afgesit. Nog voor hierdie besluit geneem is het hulle vasgestel dat die landdroste en veldkornette moes toesien dat geen byeenkomste gehou mag word of memories opgetrek word ten gunste van die kiesing van in hoofkommandant of kommandantgeneraal. Ook het daar 'n soort van versoening tussen Bührmann en Pretorius plaasgevind in teenwoordigheid van die Raad. Pretorius moes namelik aan Bührmann beloof dat hy hom nie met sake ten noorde van die $26 e$ breedtegraad sou bemoei nie. ${ }^{\text {it }}$ ) Mens vra homself af hoe dit moontlik was dat die Lydenburgers tog so'n hoë dunk van Bührmann kon hê om Pretorius voor hom te laat buig! STUART verhaal dat hy hom as wie weet wat voor hoge persoonlikheid voorgedoen het. ".)

Die ou Ohrigstadse party van J. J. Burger het nou as Lydenburgse party in in nuwe gedaante herleef, en het sterk onder invloed van Bührmann gestaan, en die onsimpatieke optrede van die Volksraad op Krugerspost waar Bührmann se invloed op die Ohrigstadters oorheersend was, het gemaak dat Potgieter en Pretorius mekaar gevind het. Op 14 November 1849 het C. B. Rabe uit Zoutpansberg aan Pretorius geskryf ${ }^{12}$ ) dat hy tot sy genoege gehoor het dat laasgenoemde daarheen wou kom, en hom meegedeel dat Potgieter hom meermale verseker het dat niemand met meer bereidwilligheid

,.de hand van vriendschap aan zijne onenige landgenoten en mede Emigranten zouden bieden als hij, indien hy slechts in zijne vorige betrekkingen gelaten word en eene verzekering kreeg dat hij van verdere belediging van de heer Bührmann zoude beschermd worden."

Pretorius het dadelik na ontvangs daarvan op 2 Desember aan Rabe teruggeskryf en ook sy begeerte na vriendskap uitgespreek, maar tegelyk ook op Bührmann as kwaadstoker gewys wat hom selfs nadat hulle op Krugerspost met mekaar afgemaak het, weer geblameer en beklad het. Potgieter het die brief gelees en het nou per-

\footnotetext{
7) Volksraadsnotule Art. 30.

8) 'n Besluit in die sin is in die notule deurgestreep. Sien end van Art. 29. Oor die indruk i.v.m. die optrede van Pretorius om dit te voorkom, vgl. $R$. 18549 Voortr. Arg. stukke bls. 396.

9) Volksraadsnotule Art. 38.

10, Volksraadsnotule Art. 43.

11) J. Stuart: De Holl. Afrikanen, bls. 195.

12) R. 185 49. Voortr. Arg. stukke, bls. 396-398.
} 
soonlik 'n baie vriendskaplike brief aan Pretorius geskryf, ${ }^{13}$ ) en hom vertel hoe Bührmann na hulle versoening aan Olifantsrivier in teenwoordigheid van baie mense gesê het hoe hy nie sal rus nie voordat hy hom, Potgieter, onder gebring het. Bührmann wat ,in geen betrekking staat" en ,die onder een schijn van vredelievendheid de grootste tweedragt zaaid."

Met 'n verbitterde gemoed het hy geskryf

"Nooit kan het ons wel of voorspoedig gaan zo lang dien man getollereerd word onder ons te blijven of zich met onzer zaken te bemoeien. Zijn plannen zijn te duidelijk te bemerken, en wee ons wanneer hij dan het hoofd des bestiers is!"

Waarom, het hy gevra, moet hulle hul dan van so'n "dolsinnige" persoon aan die neus laat lei en soveel beledigings van hom verdra?

Potgieter en Pretorius het mekaar gevind. Daar sou nog wel misverstande kom, maar hulle het tog saam gestaan, saam gewerk vir die heil van die land, saam teen die Lydenburgers met Bührmann as raadsman. Van 'n Volksraad waar die invloed van Bührmann oorheersend was. wou Potgieter nie weet nie, en eers toe Bührmann in Maart 1852 deur die Volksraad min of meer op sy plek gesit was, het Potgieter die Raad se gesag erken.

Potgieter het dan ook sy afsetting as Hoofkommandant deur die Raad in September 1849 te Krugerspost nie erken nie, en sy mense het hom in Zoutpansberg as sulks bly erken.

Pretorius het nog probeer om met die Raad saam te werk, en dinge reg te kry. Maar dit was onmoontlik, soos geblyk het op die eersvolgende Raadsvergadering wat op 22 Januarie 1850 op Potchefstroom saamgekom het en waarvan meer as die helfte van die Lydenburgse party was.

Bührmann se invloed was in hierdie sitting baie sterk. Die publiek was egter grotendeels teen hom gekant want die mense was bitter ontevrede omdat die kommandantgeneraalskap afgeskaf was. Juis in hierdie tyd het verskillende kafferstamme in Westelike Transvaal oproerig begin word. Daar het dan ook 'n memorie van 278 persone by die Volksraad ingekom waarin gevra is dat Andries Pretorius as kommandantgeneraal aangestel moes word. Die Volksraad wou dit egter nie doen nie maar wou eers die gevoelens van die publiek inwin. Die toeleg is duidelik. Bührmann het goed besef dat dit nie moontlik sou wees om in Potchefstroom die versoek sonder meer te weier nie, en daarom wou hy die beslissing laat uitstel totdat die Volksraad weer op Lydenburg sou vergader. Dit was makliker om die versoek daar te weier. Die gees van die vergadering was dan ook van so' $n$ aard dat Pretorius as lid bedank het. Sy ou teenstander.

13) R. 188 49, Voortr. Arg stukke, bls. 399-401. 
W. H. Jacobsz, het allerhande beskuldigings teen hom laat rondgaan en toe hy by die Raad daaroor gekla het, het die Raad Jacobsz onskuldig verklaar. Dit is onverstaanbaar, want die stuk wat Jacobsz laat sirkuleer het, het die grofste beledigings bevat. ") Die publiek was in Westelike Transvaal al sat vir Bührmann, en hulle het by die Raad oor hom gekla, maar die Raad het die klagte genegeer en Bührmann boonop nog as sekretaris aangestel, en toe hy eers beswaar had om die benoeming aan te neem omdat hy deur die aanklag van Pretorius ,een bevlekt persoon geworden was", het die Raad geantwoord dat hulle hom ,als zoodanig niet beschouwde" en as eerlik verklaar, en gekonstateer dat ",het genoeg gebleken is" dat die aanklagte van Pretorius ,onwettig kon beschouwd worden". Pretorius en sy mense het dan ook in hierdie raadsitting teenoor Bührmann 'n nederlaag gely.

Pretorius het nou ook die koers ingeslaan wat Potgieter reeds in Maart 1849 aan Olifantsrivier gevat het: hy het die Volksraad nie meer al te ernstig geneem nie, en het net soos Potgieter ook selfstandig as Kommandantgeneraal opgetree, en die stukke as sodanig geteken. ${ }^{15}$ ) Mens het nou die eienaardige toestand gehad dat die Volksraad wat prakties 'n Lydenburgse Raad was, die hoofkommandantskap of kommandantgeneraalskap afgeskaf het maar dat Potgieter en Pretorius tog as sodanig deur hulle volgelinge beskou is, wat same meer as vier keer soveel as die Lydenburgse groep was. Die aansien van die Volksraad het dan ook in Westelike en Noordelike Transvaal byna tot op vriespunt gedaal.

Potgieter en Pretorius het dan ook meer en meer besef dat hulle saam moet staan. Bührmann en sy Lydenburgse aanhang was hul gemeenskaplike vyand. Potgieter was alleen bang dat Pretorius op 'n goeie dag die Engelse weer in die Oranjerivier-soewereniteit sou gaan aanval. Sy stille hoop was dat Engeland in Europa in moeilikheid sou kom en daar op sy kop sou kry. Op 15 April 1850 het hy uit Zoutpansberg aan Pretorius as sy „waarde en veelgeachte vriend" geskryf :

"Ik hoor gedurig geruchten dat er weder klarigheid onder de voorste Emigrante gemaakt word om een nieuw oorlog met het het Britsche Gouvernement te beginnen; Ik hoop uit grond van mijn hart dat het leugenagtig mag zijn, geloof mij vrij dat het niet alleen vruchteloos voor ons zijn zal een langdurige oorlog met het Britsche Gouvernement te beginnen maar dat den tegenwoordigen staat der Emigranten meer vrede als oorlog vordert en er ook buitendien niets bij te haalen is, daarom laat mij $\mathrm{U}$ raaden als een vriend die waarlijk in $U w$ welvaart en in dat

14) R. $190 / 50$.

15) Reeds op 12 Februarie 1850. R. 195/50. 
van ieder emigrant oprecht belang stel, om toch geen deel daarin te nemen, de Genadige en Almachtige God die perken stelt aan vervolging en verdrukking kan ons een door oprechte getrouwheid aan Hem en aan onze algemeene belangens meer schenken als wij ooit om denken of hem om bidden kan. Beschouwd den toestand van zaaken onder het geheel der Emigranten. vraag uwe eigene ondervinding af en $U \mathrm{Ed}$. zal met mij moeten getuigen dat gij meer als eens onwetend eenen verrader tct eene vertrouweling hebt gehad en alzo een adder voor een duif hebt gestreeld. - Ik werp deze schetsen niet uit omdat ik bevreesd ben dat gij iets van dien aart van mening zi, maar wil $\mathrm{U}$ alleen op uwe hoede stellen dat gij $U$ door geen vurige vlijerij of bitsige raadslagen en beloften laat misleiden waarvoor gij alleen naderhand verantwoordelijk word gehouden en het gelag van moet betalen, den tijd van onze algemeene verlossing is nog niet geboren en den dag daarvoor kan alleen aanbreken nadat wij door onze eigene ijver, zorg en vreedzaam gedrag nevens Gods zegen tot een volk zijn geworden, aanzienlijk in getal, eendragtig, dapper, met de zwaard der Gerechtigheid in de handen en de middelen in onze kisten om strijd te voeren en te verdedigen, en God alleen weet hoe spoedig dien dag ons staat in te wagten."

Daar het nou skielik uit 'n ander hoek moeilikheid gekom. Waar daar totdusver alleen twee groot leiers, Potgieter en Pretorius, was, elkeen in groot aanhang, en verder die Lydenburgse minderheidsgroep onder invloed van Bührmann en gesteun deur die meerderheid van die Volksraad, het daar 'n vierde groepie gekom onder leiding van J. A. Enslin wat in Marico se wêreld gewoon het. Dit was egter maar klein. Enslin was 'n interessante verskyning onder die Voortrekkers. Hy het eers in die Vrystaat gewoon waar die mense van hom as die ou profeet gepraat het. Hy en sy aanhangers het iets dweperigs gehad op godsdienstig gebied en het 'n soort van sekte gevorm. Met ander mense het hulle dan ook eintlik nie gemeng nie. Sommige van hulle het so ver gegaan om te beweer dat die godsdiens ydel is daar die saligheid tog van die uitverkiesing afhang. Hulle het hierdie leerstuk so op die spits gedryf dat hulle in 'n fatalisme verval het, en hierdie gevoelens het hulle verdedig deur 'n jammer like verdraaing van die Skrif en veral van die profesieë. Hulle kinders wou hulle nie deur die predikante wat af en toe Transvaal besoek het, laat doop nie, en veral teen ds. A. Murray jr. het hulle baie beswaar gehad. Ook het hulle gemeen dat hulle deur die Trek in noordwaartse rigting nie meer ver van Jerusalem af is nie, en hulle uiteindelike doel was om daar uit te kom. Hulle getalsterkte was nie baie groot nie, maar hulle wou geen ander leier as hulle komman- 
dant J. A. Enslin hê nie. Die meerderheid van die bewoners van Marico het nie tot hierdie sektariese groep behoort nie en het besware gehad om onder Enslin as kommandant te staan, en daarom het hulle op 21 Maart 1850 aan Pretorius geskryf dat hulle regeringloos is, en het hom gevra om daar orde op sake te stel want hulle het hom as Kommandantgeneraal gekies. ${ }^{17}$ ) Pretorius is toe daarheen en het op 15 April 'n vergadering gehou waar die publiek toe Adriaan Stander as kommandant gekies het en ook 'n paar veldkornette en assistent-veldkornette. Enslin was hieroor baie kwaad en het in Stander 'n opposisie-kommandant teen hom gesien, en hy het verklaar dat hy en sy mense hulle nooit aan Pretorius sou onderwerp nie. en het die beskuldigings van $W$. H. Jacobsz teen laasgenoemde aangehaal. ${ }^{18}$ ) Ook het hy op apokaliptiese wyse gepraat van die slang aan die hemel wat nie sal ophou voordat hy die derde deel van die sterre op die aarde gewerp het nie. ${ }^{19}$ ) Die twee kommandante het dan ook glad nie saamgewerk nie. Dit was baie nadelig want Secheel het juis in daardie streke ' $n$ baie dreigende houding begin aanneem. ${ }^{{ }^{0}}$ )

Bührmann het intussen ook nie stil gesit nie. Hy het hard teen Pretorius en Potgieter georganiseer en lyste rondgestuur, ook aan Enslin se mense, om naamtekeninge te versamel teen die aanstelling van 'n kommandantgeneraal. Die Volksraad het op 20 Mei op Lydenburg saamgekom. Die meerderheid was ou Ohrigstadters. W. H. Jacobsz en Bührmann, altwee skerp teenstanders van Pretorius, is as voorsitter en sekretaris gekies. Deur die agterafse organisasie van Bührmann het daar omtrent net lyste van die aanhangers van Lydenburg ingekom waarin die meerderheid hom teen die aanstelling van ' $n$ kommandantgeneraal verklaar het. Die Raad het dan ook so besluit, en het ook nog Steph. Schoeman as provisionele kommandant vir Potchefstroom aangestel. Dit was 'n onverstandige set van die Lydenburgers, want met die bestaande kommandant, J. J. Jacobs, is geen rekening gehou nie. Die toeleg was duidelik: hulle wou verdeeldheid onder die mense van Pretorius bring, en wou in 1851 poog om teenoor Pretorius ook 'n opposisie-generaal in Potchefstroom te benoem. Bührmann het nou teen Pretorius geseëvier.

Pretorius het intussen kalm sy gang gegaan om sake te probeer reg kry, ook met die Engelse. Potgieter wou met die Engelse niks te doen hê nie en het liewer verkies om telkens weg te trek, al was dit ook onder die Portugese in. Pretorius het egter gemeen dat dit beter was om deur onderhandelings die Engelse agressie te keer, en het dan ook op 18 Junie 1850 aan Majoor Warden van Bloemfon-

\footnotetext{
1i) $R .198 / 50$; R. 201/50.

18) V.R. $103 / 50$.

19) $R .212 / 50$.

20) R. 209/50.
} 
tein geskryf dat hy van plan was om met die Britse Parlement in Londen in verbinding te kom en te vra dat 'n paar onpartydige kommissarisse aangestel word om die kwessies van 1848 en later tussen die Engelse en die Emigrante te ondersoek. ${ }^{21}$ )

Die besluit van die Volksraad om die afskaffing van die kommandantgeneraalskap te handhaaf het die mense in Westelike Transvaal nog meer ontevrede gemaak. Hulle het besef dat Bührmann daar agter gesit het. ${ }^{22}$ )

Toe die Volksraad op 16 Oktober 1850 in Potchefstroom bymekaar kom, was die toestand baie gespanne. Die ontevredenheid onder die publiek het byna die breekpunt bereik. Temidde van die dreigende kafferonluste was die mense sonder kommandantgeneraal weerloos. Die Volksraad het dan ook toegestem dat die hele publiek en nie net Bührmann se satelliete nie, hulle duidelik oor die saak sou uitspreek, en het toegestem dat Pretorius intussen tot op die wal van Vaalriver as kommandantgeneraal kon optree. Van die 26e breedtegraad is geen woord gerep nie. En dan wou die Raad op die eersvolgende sitting al die bestaande kwessies laat uitmaak.

Potgieter het op 6 Januarie 1851 aan Pretorius en sy mense geskryf dat hy nog altyd begerig was om met die ander Emigrante onder een bestuur te wees. Hy het hom egter afsydig gehou omdat daar meermale gerugte was dat Pretorius opnuut die Engelse in die Soewereniteit wou aanval, en dit wou hy nie, want dit sou alleen moeilikhede met Engeland gee. ${ }^{23}$ ) Hierdie gerugte was egter heeltemaal onjuis. Pretorius het glad nie aan aan so iets gedink nie, en dit was Bührmann wat dit rondgestrooi het, en van Pretorius en van sy mense as die ,oorlogsparty" gepraat het.

Die Raad het op 15 Januarie 1851 aan Pienaarsrivier saamgekom, 'n neutrale plek tussen Potchefstroom en Lydenburg. Die spanning het intussen groter geword en die mense het gewapend opgekom om die aanstelling van in kommandantgeneraal, 'n militêre hoof, te eis. Die krygsraad was ook aanwesig. Hoewel Bührmann weer hard georganiseer het was die Volksraad verplig om vir 'n dag te verdaag en die vraag oor die aanstelling van 'n kommandantgeneraal vir advies in die hande van die krygsraad te stel. Op die vergadering van hierdie liggaam was die landdroste van Potchefstroom en Lydenburg, Andries Pretorius, drie kommandante, veertien veldkornette en vier privaat persone uit Lydenburg aanwesig. Die eenparige aanbeveling was om vier kommandantgeneraals aan te stel: A. W. J. Pretorius vir Potchefstroom. Magaliesberg en 'n gedeelte van Marico; A. H. Potgieter vir Zoutpansberg; W. F. Joubert vir Lydenburg en J. A.

21) R. $215 / 50$.

22) R. $219 / 50$.

23) R. 248,51 . 
Enslin vir 'n gedeelte van Marico. In plaas van twee generaals was daar dus nou vier. Die Lydenburgers wou onder invloed van Bührmann nie onder Potgieter of Pretorius staan nie, terwyl die klein klompie Jerusalemgangers in Marico weer deur hulle sektariese neigings apart gestaan het en alleen Enslin as hulle voorman wou hê.

Die vier generaals het van die Volksraad 'n vasomlynde instruksie ontvang. ${ }^{24}$ ) Hulle moes 'n eed aflê dat hulle hierdie instruksie sou uitvoer. Hierin was bepaal dat hulle teen buitelandse- en binnelandse vyande moes waak en dat hulle nie met enige buitelandse moondheid sonder die Volksraad sou onderhandel nie. Ook moes hulle waak teen binnelandse verdeeldheid in die Staat. ${ }^{25}$ ) In hulle afdelings moes hulle toesig hou oor die naturelle, dus optree as superintendente van naturellesake. Pretorius, Joubert en Enslin is tydens hierdie sitting van die Volksraad ingesweer: die instruksie is in de Raadsvergadering deur Bührmann aan hulle voorgelees en hulle het dit geteken. Potgieter was nie aanwesig nie en dit is besluit dat hy by ' $n$ latere geleentheid moes insweer. Stephanus Schoeman is as vaste kommandant van Potchefstroom benoem en die opposisie teen kommandant J. J. Jacobs bestendig. Straks sou die Lydenburgers probeer om in Potchefstroom 'n opposisie-generaal te benoem. Die mense moes op die wyse van Pretorius afvallig gemaak word. Die Volksraad het verder in verband met die twis van Bührmann met Pretorius besluit om gewoonweg te belet dat daar verder getwis of oor die saak gepraat moes word. Dieselfde is oor die twis van W. H. Jacobsz en Pretorius besluit.

Toe die Volksraad uiteen is het die onenigheid deur die stelselmatige optrede van Bührmann weer hoog opgevlam. Dit sal onthou word hoe Pretorius met die Volksraadsitting in September 1849 op Krugerspost aan Bührmann moes beloof dat hy hom nie met sake ten noorde van die $26 e$ breedtegraad sou bemoei nie. Niemand het geweet waar hierdie graad loop nie. Alleen dat dit min of meer reg wes van Delagoa baai was. Volgens besluit van die Volksraad van Potchefstroom in Oktober 1850 sou Pretorius voorlopig as kommandantgeneraal ageer tot op die wal van Vaalrivier. En nou, op Elandsrivier, het die Volksraad Pretorius aangestel as kommandantgeneraal vir Potchefstroom, Magaliesberg en gedeelte van Marico. Na die sitting van die Volksraad het hy die instruksie vir die kommandantgeneraals ontvang. Dit was deur Bührmann geskryf. Toe hy dit by die huis nog in keer lees vind hy dat die aanhef daarvan as volg gelees het:

$2+$ Soutter Kol. Pak. I, No. 14.

25) Ulit die feit dat daar vier kommandantgeneraals benoem is, het die legende ontstaan dat daar ook vier Republieke sou gewees het. Maar dit is 'n legende. Die vier kommandantgeneraals was aan een en dieselfde Volksraad onderworpe, en moes volgens hulle instruksie juis die eenheid in die cen Republiek bevorder. 
„Instruktien voor de Kommandant Generaals onder gezag en verantwoording van den Ed. Volksraad benoorden den 26 graad. Hollandsche Africaansche Emigranten benoorden deze landstreek zal in wijken en districkten verdeeld worden daar hunne respektive generaals kommandants en veldkornets zal aangesteld worden onderhewig aan zoodanige veranderingen als de tijd en omstandighede vereist."

Bührmann het by die voorlesing van hierdie instruksies met die beëdiging van die generaals hierdie aanhef nie gelees nie. $\left.{ }^{28}\right)$ Pretorius het dus iets beëdig wat fataal was en wat nog deur die krygsraad nog deur die Volksraad bepaal was. Die Volksraad het dus hiermee, miskien onwetend, alle gesag ten suide van die 26 e breedtegraad feitlik losgelaat en Pretorius se kommandantgeneraalskap was van nul en generwaarde omdat sewe-agstes van sy gebied ten suide van hierdie breedtegraad geval het. Dit was 'n bedrog van baie ergerlike soort en die bom het dan ook hewig gebars.

Pretorius was verontwaardig toe hy na afloop van die Volksraadsitting die aanhef van die instruksies onder sy oë kry en sien dat hy hom nie met die aangeleenthede ten suide van die breedtegraad mag bemoei nie, juis waar sy mense gewoon het! Hy het op 3 Februarie 1851 sy ontevredenheid per brief aan die Volksraad te kenne gegee. ${ }^{27}$ ) Hy het op die erns gewys, ook dat daar in Zoutpansberg ontevredenheid teen Potgieter opgekom het, en daarop gewys dat hulle moet oppas dat hulle nie weer vir hulle ,een koevoed smeeden" moet om hulself te breek nie. Hierdie brief teken Pretorius se gemoedstoestand. Hy het nooit aan die stories omtrent die ses-entwintigste breedtegraad enige waarde geheg nie, hy wou die onafhanklikheid tot op die wal van die Vaalrivier bewaar, en nou gaan die Volksraad al die grond tussen die Vaalrivier en die 26 e graad, d.w.s. die hele Transvaal Hoëveld. prys gee net om hom klein te kry.

Die Lydenburgse landdros het daardie distrik se volksraadslede saamgeroep en op 15 Februarie het hulle 'n kommissieraad gehou. Hulle het 'n brief aan Potgieter geskryf dat hy ook as kommandantgeneraal moes kom insweer, en hom daarin as "voormalige Hoofd Kommandant Generaal" betitel, iets wat nie sou bygedra het om hom inskikliker te stem nie. want sy volgelinge het hom nog steeds as kommandantgeneraal beskou. Die Lydenburgers het aan Pretorius ook geskryf as antwoord op sy brief van 3 Februarie. ${ }^{28}$ ) In verband met die ses-en-twintigste breedtegraad waaroor hulle so'n drukte gemaak het, het hulle 'n komiese figuur geslaan. Hulle het in die brief verklaar dat hulle self ook nie weet waar die graad loop nie en dit

26) Stuart : De Holl. Afrikanen, bls. 194.

27) V.R. $154^{\prime / 51}$

28) Kommissieraadsnotule 15 Feb. 1851. Art 4. 
baie graag self wou uitvind, maar hulle is te onvermogend om dit te doen, en daarom moes Pretorius "hoe duister de instruktie ook mogen zijn", daarin berus. Hulle het Pretorius se opmerking in verband met Potgieter en sy mense heeltemaal verkeerd verstaan en hom verwyt dat dit hy self. saam met die krygsraad was, wat Potgieter as kommandant-generaal wou hê! En dit terwijl Pretorius geen woord teen Potgieter geskryf het nie. Hy het later dan ook aan die Lydenburgers geskryf dat hulle hom oor Potgieter verkeerd verstaan het. ${ }^{29}$ ) Ook het hulle aan Pretorius geskryf dat hulle van plan was om in Mei met die sitting van die Volksraad met die Britse regering te gaan onderhandel.

Pretorius het vir hierdie laaste mededeling baie geskrik. Hy was bevrees dat die Lydenburgers deur 'n onderhandeling met die Engelse hierdie beste en digsbevolkte deel van die land tussen die Vaalrivier en die ses-en-twintigste graad sou gaan prys gee. Die mense wat in hierdie gebied gewoon het, was net so ontevrede. Die ontevredenheid het nog groter geword toe Steph. Schoeman, wat deur die Lydenburgers as opposisie-kommandant in Potchefstroom aangestel is, hom nou met die aangeleenthede in die wyk van kommandant J. J. Jacobs gaan bemoei het. ${ }^{30}$ ) Die mense het nou begin memories optrek teen die aanhef van die instruksie in verband met die ses-en-twintigste graad. Uit Suikerbosrand het hulle gevra om die hoofstad ergens in die sentrum van die land te mak, en dit nie op 'n uithoek as Lydenburg te hou nie. ${ }^{31}$ ) Lydenburg was wel nie die hoofstad nie, maar die Lydenburgers het dit tog as sodanig beskou. En hulle het ook gevra dat as die Lydenburgers aan die Engelse wil skryf dit eers op 'n Raadsitting midde in die land behandel moes word.

Pretorius het op 6 April weer aan die Volksraad geskryf. ${ }^{32}$ ) $\mathrm{Hy}$ het daarop gewys hoe dat die ontevredenheid oor die houding van die Volksraad in verband met die ses-en-twintigste breedtegraad toeneem. Hyself was ook baie ontevrede, want hoe kon hy sy plig uitvoer as die Raad hom dit tegelyk verhinder? Ook het hy aangedring dat hulle nie aan die Britse regering moes skryf alvorens hulle dit op 'n vergadering ,,in het midden der dikke bevolking" behandel het. Hy het ook sy besware te berde gebring dat die Raad nou praat van die besluite van Olifantsrivier in Maart 1849 wat nog deur Potgieter nog deur hom ooit aanvaar is, terwyl die van Derdepoort in Mei 1849 , waar die band van vereniging gelê, deur die Volksraad verbygegaan word. Dit sal onthou word dat die besluite van Olifantsrivier net van die ou Ohrigstadters was, en die van Derdepoort van al die par-

\footnotetext{
29) V.R. 157/51, ged. 6 April 1851.

30) $R .260 / 51 ; V \cdot R .157 / 51$

31) V.R. $156 / 51$.

22) V.R. $157 / 51$.
} 
tye. Olifantsrivier het aan die Lydenburgers 'n oorheersende posisie gegee, terwyl Derdepoort aan geen seksie so'n oorwig toegeken het nie. Dit was hierdie oorheersende posisie van die Lydenburgers, wat 'n minderheidsgroep was, wat al die moeilikhede veroorsaak het, terwyl Buhrmann weer in daardie minderheidsgroep gedomineer het. Pretorius het verder die Raad daarop gewys dat hulle sy opmerking oor Potgieter verkeerd verstaan het. Hy was nie teen Potgieter nie. Op 30 April skryf Pretorius weer aan die Volksraad en wys hy weer op die groeiende ontevredenheid oor die feit dat die Volksraad die gebied tussen Vaalrivier en die ses-en-twintigste breedtegraad wil prysge, en weer waarsku hy om nie van uit Lydenburg aan die Britse regering te skryf nie, ,maar van uyd het midden der bevolking. ${ }^{.33}$ ) Dit is duidelik: hy was bevrees dat die Lydenburgers hierdie gebied aan die Engelse sou afstaan.

Die Volksraad het op 5 Mei op Lydenburg bymekaar gekom. Die Potchefstromers kon nie aanwesig wees nie, maar die Lydenburgers het hulle met ander persone uit daardie distrik aangevul en gemaak of hulle die Volksraad was. W. H. Jacobsz. Pretorius se teenstander was voorsitter. Aan Pretorius se besware is dan ook nie tegemoet gekom nie. Die Potchefstroomse en Magaliesbergse raadslede het toe op 30 Mei saamgekom en gewoonweg besluit om die beperking van die ses-en-twintigste breedtegraad weg te neem, en het bepaal dat Vaalrivier die suidelike grens van die Republiek sou wees; Lydenburg kon maak wat hy wou.

Die Volksraad het hom van dit alles nie veel aangetrek nie, en het die briewe van Pretorius en die vertoë van die publiek genegeer. en dit terwyl dit in heel Suid-Afrika gegis het en die kafferstamme oral oproerig wras. Hierdie onrus het gemaak dat daar meer en meer stemme, ook in Engeland, teen die anneksasie-beleid van Sir Harry Smith opgegaan het, en die gedagte dat Engeland sy gesag moet terug trek, het steeds sterker geword. Die Britse gesag in die Soewereiniteitsgebied is dan ook swaar op die proef gestel. Die mense het daar selfs openlik die hulp van Pretorius ingeroep. Hulle wou hê hy moes daarheen gaan om orde op sake te stel. Met die oog op dit alles het Pretorius besef hoe belaglik dit was dat die vraag of die Vaalrivier die suidelike grenslyn van Transvaal was, opgelos moes word. Omdat die Volksraad aan die 26ste breedtegraad vasgehou het en die versoekskrifte van die Potchefstromers genegeer het, het Pretorius besluit om die knoop deur te hak. Hy het die publiek opgeroep om op 8 September 1851 op Rustenburg met die Volksraad en die Krygsraad te vergader. Die Volksraad moes dan aan die publiek verslag doen van sy werksaamhede. Die Volksraad het egter nie opgedaag nie,

33) V.R. 163,51 
en toe het die krygsraad die sake in hande geneem. ${ }^{34}$ ) Hierdie liggaam het die besluit van die Volksraad om die gebied tussen die26ste breedtegraad en die Vaalrivier los te laat, vernietig, en ook bepaal dat die Volksraad hoegenaamd geen reg sal hê om sonder nadere instruksies van die publiek met enige Buitelandse moondheid te onderhandel. Die toeleg is duidelik: die krygsraad was bang dat die Volksraad met die Britse gesag sou gaan onderhandel en dan die hele Hoëveld tussen die Vaalrivier en die 26ste breedtegraad aan Engeland sou gaan prys gee. Pretorius se gedagte was om nie nog meer grondgebied aan Engeland af te staan nie, maar inteendeel, om die soewereiniteit weer terug te kry van Engeland. Die publiek het aan die krygsraad opgedra om die werk van die Volksraad te doen. Verder het die krygsraad aan Pretorius cpdrag gegee om saam met twee persone wat die publiek sou kies, te trag om die sake in die soewereiniteit reg te makk en 'n goeie verstandhouding tussen die Britse goewerment en die Emigrante te bring, en ,te trachten bloedstrortingen voor te komen."

Pretorius het die volgende dag aan die Britse Resident in Bloemfontein, Majoor Warden, van hierdie besluite kennis gegee. Op 4 Oktober het hy weer aan Warden geskryf. Op 10 Oktobe, r het Warden teruggeskryf dat die Britse goewerment ook begerig was om tot $n$ goeie verstandhouding te geraak. ${ }^{36}$ ) Pretorius het Warden op 10 November geantwoord ${ }^{37}$ ) en op dieselfde dag ook die voorsitter van die Volksraad geskryf en gevra om saam te werk want as hulle nie met Engeland tot 'n verstandhouding kom nie sou laasgenoemde nog sy planne deursit om al die gebied tot aan die ekwator te annekseer. ${ }^{38}$ ) Hy wou 'n wal opwerp teen die Britse agressie. Warden het op 18 November aan Pretorius berig dat daar begin Desember twee spesiale kommissarisse op Bloemfontein sou wees om met die Emigrante te onderhandel..$^{39}$ )

Die Lydenburgers was verontwaardig oor hierdie loop van sake. Op versoek van W. H. Jacobsz en J. N. H. Grobler het die landdros die Lydenburgse volksraadslede opgeroep. en op 27 November het hulle onder voorsitterskap van Jacobsz vergader. Bührmann was sekretaris. Hulle het besluit om H. S. Lombardt as kommandantgeneraal van Potchefstroom aan te stel in die plek van Pretorius wat dus feitlik opsy gestoot moes word. Bührmann is deur hulle as landdros van Lydenburg aangestel. Hulle het hom reeds in September daarvoor genomineer.

\footnotetext{
34) R. 310/51; V.R. 180/51

35) $R$. $320 / 51$.

36) $R .327 / 51$.

37) $R$. $338 / 51$.

38) $R$. $339 / 51$.

a9) $R$. $341 / 51$.
} 
Die krygsraad het op 10 Desember 1851 weer op Rustenburg onder voorsitterskap van Pretorius saamgekom..$^{\circ}$ ) Daar is toe aan die kommissie wat reeds benoem was om met die twee asistent-kommisarisse te onderhandel, weëns die gewig van die saak, nog enige persone toegevoeg, en die volgende dag het Pretorius aan Warden geskryf en gevra om die onderhandelinge nader aan die kant van die Transvalers te laat plaasvind, en gevra dat hulle die veiligheid van die Boereafgevaardigdes moes waarborg, net soos hulle dit doen met die van die Engelse. $\left.{ }^{11}\right) \mathrm{Hy}$ het ook nogmaals aan die voorsitter van die Volksraad geskryf en op samewerking aangedring. ${ }^{2} \mathrm{~W}$. $\mathrm{H}$. Jacobsz het hierop aan Bührmann en ander persone laat weet dat hy na Potchefstroom wou gaan om te kyk wat gebeur, en om die kwaad te keer as dit nodig was! ${ }^{+3}$ )

Hendrik Potgieter het aan sy mense geskryf dat hy onrustig voel oor die onderhandelinge met die assistent-kommissarisse. Hy was bevrees dat dit net moeilikheid met Engeland sou gee. Ook het hy laat deurskemer dat as daar onderhandel moet word, hy dit moes doer. Ook kon hy nie na die vergadering wat op 10 Januarie 1852 hieroor in Potchefstroom gehou sou word, gaan nie, want hy was siek en bedlegerig. ${ }^{4}$ ) Die tragiek in hierdie geval was dat Potgieter nie gesien het dat dit met die oog op die Britse agressie noodsaaklik was dat daar 'n skriftelike ooreenkoms met die Engelse gemaak moes word, dat hulle Brittanje se woord swart op wit moes hê.

Pretorius het sy broer Bart en D. A. Botha na Bloemfontein gestuur om reëlings met die assistent-kommissarisse oor die onderhandelings te tref, en na hulle terugkoms is op 10 Januarie 1852 ' $\mathrm{n}$ vergadering op Potchefstroom gehou waar die Lydenburgse volksraadslede, w.o. W. H. Jacobsz, en ook die Lydenburgse kommandantgeneraal. W. F. Joubert, teenwoordig was. Daar was ook 'n groot publiek aanwesig. Dit was nie 'n vergadering van die Volksraad of van die krygsraad nie, maar van persone uit altwee hierdie liggame. Met nadruk is besluit om die handelinge van die krygsraad om tot ' $n$ goeie verstandhouding met die Britse regering te geraak, goed te keur, maar met dien verstande dat die Volksraad die hoogste gesag sou bly en dat die Voolrivier en nie die 26ste breedtegraad die suidelike grens van ie Republiek is. Verder is daar vvftien offisiele afgevaardigdes gekies om met die assistent-kommissa-irse te onderhandel. Sir Harry Smith het intussen op 23 Desember 1851 deur 'n spesiale proklamasie die voëlvry-verklaring van Pretorius teruggetrek, en die afgevaardigdes is toe, vergesel van drie-honderd burgers, na Sand-
40) R. $352 / 51$.
41) R. $353 / 51$.
42) V.R. $188 / 51$.
4s) R. 358a/51.
44) R. 328/51. 
rivier in die Vrystaat, waar op 16 Januarie die bekende Sandriviertraktaat gesluit is. Dit was die kroon op Pretorius se werk. Hy het oor die obstruksie van Bührmann en die Lydenburgers geseëvier. Nie alleen was die onafhanklikheid van die Emigrante ten noorde van die $V$ aalrivier erken nie, maar ook het die gebied tussen die Vaal en die en die 26ste breedtegraad vir die Transvaal behoue gebly. Maar Pretorius was teleurgestel dat die Vrystaat ook nie in hierdie traktaat ingesluit was nie, sodat daar een groot Voortrekker-republiek ten noorde van die Oranje-rivier kon wees.

S. P. E. 